\title{
ADAPTING JOHN WATSON FROM LITERATURE TO CONTEMPORARY AMERICAN TELEVISION
}

\section{ADAPTANDO JOHN WATSON DA LITERATURA PARA A TELEVISÃO CONTEMPORÂNEA AMERICANA}

\author{
Eduarda De Carli $^{1}$ \\ Elaine Barros Indrusiak ${ }^{2}$
}

\section{Introduction}

Sherlock Holmes is the most adapted human literary character, according to the Guinness World Records of 2012, and he is almost always accompanied by his companion, Dr. John Watson, in the adventures and cases he solves. Written by the Scottish author Sir Arthur Conan Doyle in the end of the 19th century, the sixty stories that feature the detective and the doctor have been adapted since the beginning of cinema - and even before, to the stage. The characters are usually depicted in the same way, with certain characteristics that make them identifiable even for people who have never read the original texts. Depictions of the character presented in classic movie and television "[...] have focused on Holmes as the intellectual superior of a slower-witted, almost buffoonish Watson. [...] In more recent portrayals, however, Watson has changed; [...] he and Sherlock share personality traits" (TOADVINE, 2012, p. 48). Watson was this buffoonish character mostly because in the canon he is always amazed at Sherlock's deductive abilities, praising him, and his role is mostly that of a mediator between Holmes and the reader, telling us the story and also asking the necessary questions so that the process of solving the crime and the crime itself are more easily explained for the average reader.

Adaptations that update the canon to a contemporary setting are not something new; this has been a tendency since the beginning of Sherlock Holmes adaptations. In the late 1890's, Doyle himself attempted to make a theatrical version of the Sherlock Holmes stories; when he failed, he recruited William Gillette to write it, and he said "[Gillette] might marry the detective, or murder him, or do anything he pleased with him, preferring to leave a stage

\footnotetext{
${ }^{1}$ Doutoranda do Programa de Pós-graduação em Letras da Universidade Federal do Rio Grande do Sul.

${ }^{2}$ Doutora em Estudos de Literatura pela UFRGS e professora dos programas de graduação e pós-graduação em Letras da Universidade Federal do Rio Grande do Sul.
} 
detective in the hands of a master actor" (LYCETT, 2007, p. 261). In 1900, the first film adaptation was released, Sherlock Holmes Baffled, and it was a short vignette, already establishing Watson as a silly bystander. It is only in 1939, after a long string of adaptations, that the first film set in the original time of the stories is released, and that is Sir Arthur Conan Doyle's The Hound of the Baskervilles, introducing Basil Rathbone as Holmes. From then on, there have been countess adaptations from all over the world. It is in the 1950s, however, that Doyle's stories start being more prominently featured in the small screen, with major productions from both the United States and The United Kingdom. Interestingly, it is through the television series that Watson starts to gain a more relevant role in the stories, as his presence becomes a necessity for Holmes, which is going to culminate in the contemporary character acting as moderator, which will be more discussed later on.

More recently, the British network BBC started airing Sherlock, their contemporary adaptation starring Benedict Cumberbatch portraying the famous detective and Martin Freeman as his faithful companion. In 2012, the American network CBS got in contact with Sherlock's producers so that they could air the series in the United Stated, but the rights were refused. The American network, mostly known for their police procedural shows such as CSI, NCIS, and Criminal Minds, decided to air its own contemporary adaptation of Sherlock Holmes, set in New York City: Elementary. Having in mind the channel's signature style of television series, it would make sense for them to produce an adaptation following that model that works so well in American television, especially if one considers that Holmes's canonical stories follow the same procedural logic, with each novel or short story presenting one case to be solved.

In this series, Sherlock Holmes (Jonny Lee Miller) is an ex-heroin addict who has spent time in an American rehabilitation clinic, and now must live with a sober companion until he gets used to the world out of the clinic and sober life. The companion that is assigned to him is Joan Watson (Lucy Liu), and she has to accompany him everywhere, including his detective work as a consultant for the New York Police Department, the kind of work he used to do for the Scotland Yard when he lived in London. The fact that Watson is a woman in this series raised a lot of concerns from both fans and critics who assumed this would eventually lead to a romantic relationship between the main characters. However, the dynamics of their partnership has been the same since the first episode: the celebrated friendship between Watson and Holmes, with a few modifications due to the new Watson's personality and gender. 
Therefore, the objective of this paper is to identify and analyze the changes Watson goes through in the first three seasons that are pivotal to her characterization, focusing specifically on her career changes, identifying the major events that contributed to them and showing how she has a more active role in the series, given the switch from an internal to an external narrator.

\section{Theoretical Assumptions}

In Conan Doyle's work, we have a character-bound narrator, drawing from Mieke Bal (2009), who classifies the narrator in two main types: character-bound and external, mostly known as first and third person respectively. Herman and Vervaeck (2001), in The Handbook of Narrative Analysis, affirm that John Watson is an extradiegetic and allodiegetic narrator, for he "[...] is a mere witness of the things he relates" (p. 85). Their affirmation is somewhat problematic because the authors state that the intradiegetic narrator "belongs to the narrated world" (HERMAN; VERVAECK, 2001, p. 81), that is, it is a character of the story; John Watson, at the same time he narrates the story, is a character in it and narrates what he experiences. There may be different sequences of events narrated in a story, and when that happens, the classification of the narrator may vary according to the variation of events, therefore, it is not possible to affirm that he only narrates what he witnesses, especially when we consider the change from character-bound to external narrator, as it happens in movies and TV series.

In audiovisual media, we have an external camera-narrator "external, impersonal cinematic narrator, who renders the text in a non-verbal form" (BURGOYNE; STAM; LEWIS, 1992, p. 98). Peter Verstraten in his book Film Narratology (2009) proposes the idea of the filmic narrator, and it is the "agent that negotiates the relation between the auditive and visual tracks" (p. 130). Therefore, analyzing a character in a television show is a challenge, because unlike novels, in which we usually have a lot of descriptors, indications of facial expressions or more explicit thoughts and opinions given to us by the narrator, whether character-bound or external,

[...] moving-image media convey subjective interior states through the accumulation of exterior markers of what we see and hear about characters: appearance, actions, dialogue, and other sorts of evidence explicitly presented within the narrative discourse. Viewers necessarily infer and construct interior states of characters, filling in internal thoughts through a process of reconstruction and hypothesizing. (MITTELL, 2015, ebook) 
And, because of that, "while we want to gauge a character's interiority, we judge characters mostly by what they do, cued by how other characters regard, interact with, and talk about them" (MITTELL, 2015, ebook). Unless there is a voice-over expressing the character's thoughts and ideas, and even then it can be misleading if it deviates from the images on purpose, the information we have about the characters comes from an external source and is up for the viewer's interpretation.

American television theorist Jason Mittell (2015, ebook) discusses character development through time in a television series dividing it into four types. The first one is character growth, "[...] evoking the process of maturation in which a character becomes more realized and fleshed out over time"; the second, character education, "[...] in which a mature adult learns a key life lesson over the course of a series and ends up a changed person"; next, character overhaul, "[...] in which someone undergoes a dramatic sudden shift, [...] but we retain our serial memories of earlier events and relationships", and finally, character transformation "[...] with a gradual shift of morality, attitudes, and sense of self that manifests itself in altered actions and long-term repercussions".

The most common of the changes is character growth, as the viewer gets to know the characters and the writers are able to develop them more thoroughly over time. Typified or one-dimensional characters aside, it is possible to affirm that it is a general rule that characters in television series grow as episodes and seasons go by. Character education and transformation are similar, and it is possible that education can lead to transformation depending on the event, but it is also possible to identify the events that fit these separate categories.

When analyzing Elementary's Watson, it is important to consider how she behaves, speaks, how the relations with others are constructed and developed, etc, throughout the seasons, because [...] "Television characters are not like holograms. Each tiny fragment does not contain the sum of the whole, but rather becomes fully intelligible only when juxtaposed with all the other tiny fragments in all the other scenes in all the other episodes in which the character appears" (PEARSON, 2007, p. 42-43).

Therefore, the analysis of Joan must be drawn from examples found in episodes from more than one season, so that we can also show how the character has evolved since the first episode of the first season, and what changes she has been through. 
Conan Doyle's Watson, “[...] With his physical capabilities and his average, though not genius intellect, meets the definition of the hearty, average middle-class man." (TOADVINE, 2012, p. 52). He is a mediator between Holmes and the reader, asking for explanations and always praising Holmes for his abilities, or astonished that Holmes ignores certain things of more "popular" culture, literature or even world events. He is the character with whom the average middle-class reader would identify with in the stories.

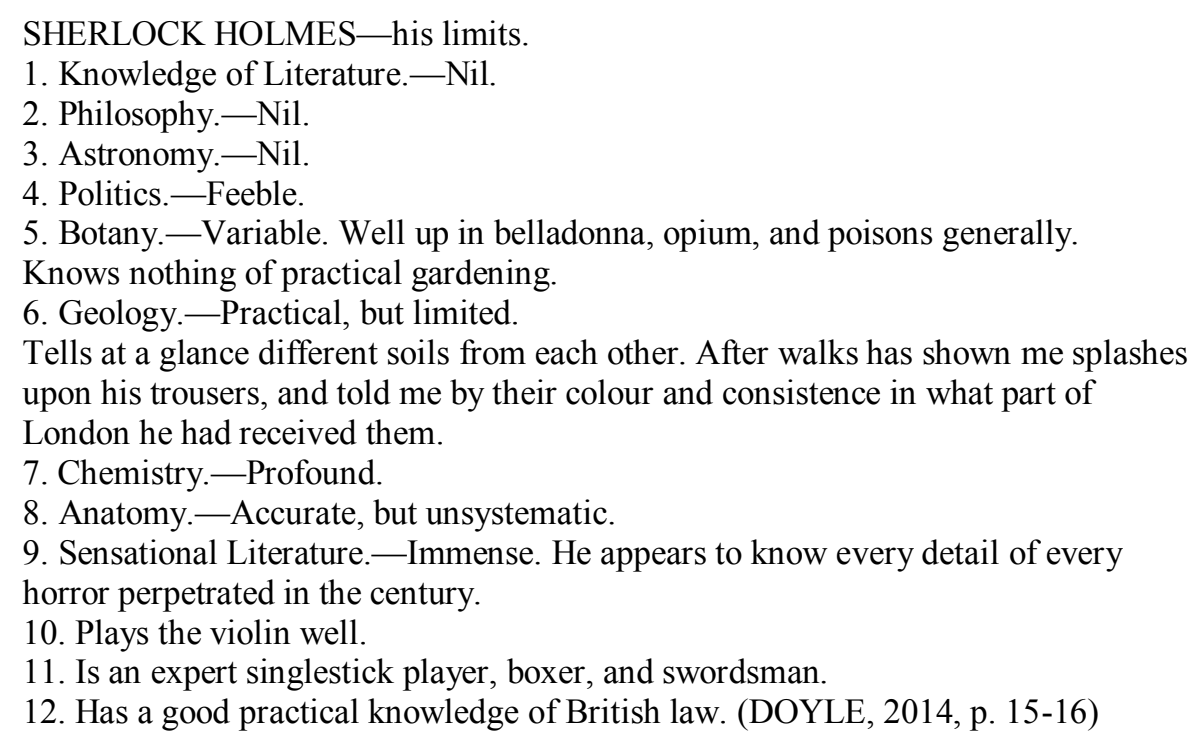

This shows that even though Watson will later on in the stories be completely in awe of what Holmes does, he is also very judgmental and the one who delineates all the characters for the reader. As a result, his own characterization in the stories is built not only by what he says about himself, but also by what he says and thinks about the other characters, especially Holmes. Watson is very analytical from the first story onwards, considering everything that he writes about the detective's behavior and impressions of the cases. It is possible to see that Watson has a potential for the investigative business, but he does not develop this skill in Conan Doyle's works, at least not to the extent Joan Watson does with Sherlock's aid in Elementary.

In the original stories, Watson is representative of Victorian morality, according to April Toadvine (2012), especially in his reactions to Holmes, which "[...] often stem from a familiarly Victorian code of behavior that privileged work ethic, respectability, and modesty" (p. 53), being the "[...] voice of social norm at 221B" (TOADVINE, 2012, p. 53). One can see this clearly in the beginning of the short story "The Musgrave Ritual", when he extensively 
talks about Holmes's untidiness, considering himself virtuous when compared to the detective.

$++[\ldots]$ he was nonetheless in his personal habits one of the most untidy men that ever drove a fellow-lodger to distraction. Not that I am in the least conventional in that respect myself. The rough-and-tumble work in Afghanistan, coming on the top of a natural Bohemianism of disposition, has made me rather more lax than befits a medical man. But with me there is a limit, and when I find a man who keeps his cigars in the coal-scuttle, his tobacco in the toe end of a Persian slipper, and his unanswered correspondence transfixed by a jack-knife into the very centre of his wooden mantelpiece, then I begin to give myself virtuous airs. (DOYLE, 2012, p. 425)

But even more than heightening this contrast in behaviors and morality, he is the one who acts as a stand-in for the reader, asking Holmes the questions needed for us to understand his process of solving the crime; due to his constant questioning and need for explanations he is, however, most often taken to be of a lesser intellect as compared to the reader, making his most common portrayal in the history of adaptations to be that of a buffoon, inaugurated by Nigel Bruce's interpretation of the role.

Within this Victorian code of behavior, one important element is the separation of the domestic/private and the public spheres, especially when it comes to family matters. While family is important to Watson, and we see this - albeit superficially - through his relationship with the woman who later becomes his wife, Mary Morstan, his connection to Holmes is still the most prevalent in his stories. Of course, this is due to the stories being about the adventures of the detective and not about Watson himself, but this seems to emphasize the fact that "[...] The domestic sphere is therefore not only antithetical to the investigative sphere, but actually works to reinforce the appeal and emotional significance of the detective's professional and homosocial connections” (MELDRUM, 2015, p. 210).

These elements, so characteristic of the times the characters were living in, need then to be adjusted when adapting to a 21 st Century New York and not only that, when transforming Watson into a woman. An unmarried woman living with a single man would not be acceptable when Doyle wrote the original stories, but it can be portrayed in contemporary times; the relationship between the characters does not evolve into romance from the friendship that we already know so well, thus keeping the original idea of a homosocial context of the stories, now modified accordingly to a heterosocial context. The new Watson, however, will defy the morals alongside Holmes, from changing careers to standing with Holmes in his illegal acts and "immoral" behaviors.

Considering that actors can be texts in themselves (MAST, 1982), the choice of actress to play Joan Watson speaks volumes. Lucy Liu has been part of action movies, especially 
blockbusters such as the 2000 franchise of Charlie's Angels and Tarantino's Kill Bill series ; her casting, therefore allows some speculation as to traits of the character: a physically active, restless woman who gets involved in field investigations alongside Holmes and who at some point may be involved in body combat or martial arts. There is, of course, the possibility for this text to be challenged and surprise the viewers, but so far this has not been the case in

\section{Elementary.}

Joan Watson, in the series, works as a mediator between Holmes and society; she calls his attention when he says or does something inappropriate or inconsiderate, especially when they're talking to victims' families. She usually apologizes to the people and excuses Holmes, but when they are alone she confronts him about his attitudes and what is socially acceptable. She is "[...] a moral and social counterweight to Sherlock Holmes" (TOADVINE, 2012, p. 57), still maintaining the aspect of opposition in their characteristics, at least initially.

It is not from this adaptation that the idea of Watson as a mediator arises. The Fox series House $^{3}$ is the pioneer in portraying Watson, or better, Wilson, in a role that is responsible for mediating Sherlock's - or House's - interactions with the rest of humanity, also controlling him and being the only one who can successfully step up and intervene when necessary. Actually, this idea of the character as a mediator is not new; as previously mentioned, the original character is seen as a mediator between Holmes and the reader, as a way of "simplifying" the deductions, being regarded as the average Victorian Englishman to whom the public could relate, always in awe of Sherlock's abilities and praising him. This is also present in BBC's Sherlock, but in Elementary, this astonishment over the deductive reasoning is not the same: while Watson is indeed impressed with what Holmes can do, because of her initial contact with him as a sober companion, she is the one who can mediate and call his attention to his reckless behavior whenever needed.

Slowly, as a result of her interventions, we can see that Holmes changes and is able to be more considerate or even realize when he is being too impolite or inappropriate. This can be considered character education, in Mittel's taxonomy, because he does not completely change his behavior, but has learned from her. When he talks about the balance in their friendship in the nineteenth episode of the third season, he mentions that for him, friendship is about moving towards the best qualities of the other person, so Watson not only goes through

3 The series ran from 2004 to 2012, and it is considered an appropriation of Sherlock Holmes due to small details such as the surnames of the characters, House and Wilson in relation to Holmes and Watson - with House being a play on the word Ho(l)mes; House's apartment is the same number as Sherlock Holmes's, and the fact that the main character acts as a detective investigating mysterious diseases. 
changes herself in the series, but is able to inspire and provoke them in other characters, especially Holmes.

The new Watson is an athletic person; she is introduced to us in the series when she is jogging - which also serves as an introduction to the setting of the episode, contemporary New York City. She is also more than once seen going out for a jog and even inviting Sherlock to join her, which never works. He teaches her singlestick, and wants her to train in at least one martial art so she can improve her self-defense skills, which he deems essential to the kind of job they do, especially after she is attacked in their home by a suspect in one of the cases. She's also characterized as slightly stereotypically American in regards to sports, loving baseball and football, watching the games and reacting very strongly to them, while Holmes just rolls his eyes at her - so the typical Victoriana has been replaced by the typical Americana.

Her knowledge of pop culture, b-movies, and videogames comes in handy in some cases; she claims to know such things because of her brother, but this is similar to canonical Watson's role in keeping abreast of such "mundane" things while Sherlock is more preoccupied in learning and memorizing what he considers important and relevant to the detective work. Elementary's Watson also judges Sherlock for not being knowledgeable, but the perks of modernity are that he is able to research whatever he does not know instantly on his smartphone, which he also uses to identify murder victims or research related cases in online newspapers and magazines.

Joan goes through many professional changes throughout the seasons, which are triggered by major events - mostly tragedies. The first one is external to the diegesis, but is still worth mentioning because it becomes relevant in more than one episode and sometimes it is what moves the cases forward: her medical knowledge. Watson starts her professional career, or at least as far as we know, as a surgeon and, due to the death of a patient by her hands, her medical license is suspended, but she decides to quit medicine and becomes a sober companion. This career choice is motivated by her ability to deal with addicts, which comes from her experience with an ex-boyfriend. We discover this in episode 1x09, when Joan is not a detective yet, but helps Liam, the ex-boyfriend, and tells Sherlock that she learned how to deal with people like him because of that previous experience, and that when she quit medicine, aiding recovering addicts in reconstructing their lives seemed a natural choice.

Her responsibilities as a sober companion are to monitor the clients, going to meetings with them, helping them adjust to life outside of the rehabilitation clinic, all while living with them. She moves in with Sherlock in the first episode of the series; the building belongs to his 
father, and for Sherlock to live there he must stay sober, so his father hires Joan to help him during the first weeks. She explains that initially they cannot be apart for more than 2 hours, and if they are, she needs to perform a drug test to check if he is still sober. Because of this rule, she has to go with him when he is working cases for the New York Police Department. Though Holmes introduces her as his personal valet, later we find out that Captain Gregson already knew about Sherlock's past and Joan's real profession.

From the moment she starts being Sherlock's sober companion, however, we can see that she is able to help him not only in the post-rehab adjustment, but also in the cases - the first case in the show, in the Pilot episode, is solved because she notices some information in a medical file, a small detail that makes her analyze the crime scene photos again and find an incriminating evidence.

The next change in her career is somewhat natural; after Sherlock tortures the man he believed to have killed the love of his life, she stays even though her contract as a companion has ended and his father refuses to renew it. Sherlock is too raw to be left alone after what happened, so she decides to stay and keep accompanying him in the investigations. He invites her to stay as his apprentice and, as her training evolves, she becomes his partner. This change feels natural because she was already helping him with every single case since the beginning, either with her medical knowledge, pop culture references or even by offering an alternative view of the case. Sherlock notices that, that she is happier helping in the cases and being a detective than she is as a sober companion, and he invites her to stay.

It is interesting to see the changes she goes through in the episode in which she starts her new career as a detective, which is the 17 th episode of the first season, entitled "Possibility Two". The episode opens with a case, and while the police are waiting for Sherlock to say what he has deduced, he puts Watson on the spotlight and asks her what she thinks has happened. She is surprised, and stutters a little before analyzing the scene and speaking her mind. It is possible to see the difference between her and Sherlock; she is very unsure and uses words like "I think" and "maybe", while he speaks with certainty. The second time she is put on the spotlight in the episode to analyze the crime, she still is surprised and very self-conscious of her analysis, and again Sherlock is confident, assertive in what he says. When she confronts the major suspect with the NYPD to make the arrest, she is confident and speaks with certainty, affirming what she believes to be true. What is interesting about that is that their dynamic is balanced: Sherlock is not the only one with superior intellect; he knows he is above average, but Joan's abilities are equally relevant and sometimes the cases are solved because of her, which breaks the traditional notion that Sherlock is superior to Watson, 
a character whose function is often limited to being in awe or to "explain" the cases to the reader. Joan's intellect is as important as Sherlock's.

During the second season, there are no major events that influence her career as in the first, but at the end of it, Sherlock moves back to London after being involved in a case with his brother, who he discovers is an MI6 agent. When season three opens, viewers are informed that six months have passed. We see a Joan who has really grown as a detective in Holmes's absence. She has her own apartment, is still a consultant for the NYPD and she is also a private detective. She has developed her skills so much that Captain Gregson tells Sherlock that his return as a consultant to the NYPD depends on Joan's opinion, because she has done a "stellar" work and he will not lose her, even if it means gaining Sherlock. This reinforces the questioning of Sherlock's intellectual superiority, and we might say it somewhat downplays it.

With Sherlock's return, a new character is introduced: Kitty, his new apprentice and possible future partner that he met in London during a case with the Scotland Yard. He sees in her a similar potential that he saw in Joan, and he takes her under his wing so she can study, train, and learn how to be a detective. She goes to New York with him, and this provokes a new development in Joan's relationship with Holmes; he explicitly starts to see Joan as a detective in the same level as he is, so he asks her to help him mentor Kitty to become as good as her.

The other event that calls for a change, though not exactly in Joan's career, is the murder of her boyfriend, planned by what has become her arch-enemy, Elana March. His death leads to her moving back to the brownstone with Sherlock, triggering a major change in her behavior, albeit not exactly positive. She starts to isolate herself, dismiss her other friends, focusing solely on the detective work, at least until Sherlock confronts her in episode 19, "One Watson, One Holmes" because she has been acting too much like him, and their friendship depends on a balance they need to find again. As the title of the episode suggests and Holmes states - there needs to be one Holmes and one Watson, so even though they share some characteristics, there needs to be a balance and a differentiation between them.

Both Joan's career changes from surgeon to sober companion and later from sober companion to detective can be considered character transformation, in Mittell's terms, because they are gradual processes that end up changing her life completely with long-term repercussions. One could argue that her boyfriend's death in season three meets the definition of character overhaul, and not transformation, in the sense that Watson's behavior changes drastically. But that is understandable due to the circumstances, and though the changes may 
seem abrupt, especially in regards to her relation with Holmes, they actually transform her character more gradually throughout the rest of the season, Therefore, by not limiting the scope to one single episode, but analyzing the narrative arc of the whole season, one realizes that the traumatic event yields to transformation rather than overhaul, a clear indication of the characterization of Joan Watson as a strong woman.

Her first case as a detective is considered character education because she was already developing her skills since the first episode, and while under Sherlock's training, she learns several key lessons that will end up changing her character's way of dealing with events, her relationship with Holmes and her other friends. When Sherlock leaves, she has to learn quickly how to adapt to life without his partnership and grows into her own skin as a detective, but this happens off-screen. And, due to this, she can be a mentor to Kitty as she has learned a lot over the course of the three seasons.

\section{Final considerations}

Joan Watson goes through a considerable number of changes throughout the first three seasons of the series, her character being developed gradually and consistently according to those changes and their influences in her behavior, relationships, and even morals. Applying Mittell (2015) rationale, the changes most frequently identified are education and transformation, emphasizing the idea that characters in television are slowly developed due to the availability of longer time in comparison with feature movies.

Joan can be seen as a mix between an updated literary Watson and some of Holmes's characteristics, especially his detective abilities. This ends up influencing their relationship; it has traits of the canonical dynamic, but because she seldom accepts Sherlock's peculiarities without questioning or criticizing him, they end up developing a closer friendship than is usually portrayed. With this, we can see that Elementary not only questions Sherlock's famous intellectual superiority as compared to Watson but also brings the former assistant to the position of an equal, letting go of the canonical Watson's strong sense of morals in their investigations when resorting to illegal acts, such as breaking and entering, to advance in the cases. With this, Joan Watson has indeed a more active role; she's still a mediator (TOADVINE, 2012), but that is not her only function anymore; the change from the literary character-narrator to a TV camera-narrator allows for the emergence of a new Watson, one that challenges gender roles and updates Conan Doyle's work for $21^{\text {st }}$ century avid viewers. 


\section{REFERENCES}

BAL, Mieke. Narratology: introduction to the theory of narrative. 3ed.Toronto: University of Toronto Press, 2009.

BOCHMAN, Svetlana. Detecting the technocratic detective. In: PORTER, Lynnette. (ed.). Sherlock Holmes for the 21st Century: Essays on new adaptations. USA: McFarland, 2012.

BURGOYNE, Robert; STAM, Robert; FLITTERMAN-LEWIS, Sandy. New vocabularies in film semiotics: structuralism, post-structuralism, and beyond. London: Routledge, 1992.

DOYLE, Arthur Conan. C. A Study in scarlet. London: HarperCollins Classics, 2012.

DOYLE, Arthur Conan. The complete Sherlock Holmes. Volume I. United States: Sterling Publishing Co, 2012.

DOYLE, Arthur Conan. The hound of the Baskervilles. London: HarperCollins Classics, 2012.

ELEMENTARY. Created by: Robert Doherty. Produced by: Robert Doherty, Sarah Timberman, Carl Beverly. USA: CBS Television Studios, 2012 - present. 5 seasons, 120 episodes. $45 \mathrm{~min}$. son., color.

HERMAN, Luc; VERVAECK, Bart. Handbook of narrative analysis. Lincoln: University of Nebraska Press, 2001.

HOUSE M.D. Created by: David Shore. Produced by: Gerrit van der Meer, Paul Attanasio, Peter Blake. USA: Bad Hat Harry Productions, 2004 - 2012. 8 seasons, 176 episodes. 44min., son., color.

LAVIGNE, Carlen. The noble bachelor and the crooked man: subtext and sexuality in the BBC's Sherlock. In: PORTER, Lynnette. (ed.). Sherlock Holmes for the 21st century: Essays on New Adaptations. USA: McFarland, 2012.

LYCETT, Andrew. The man who created Sherlock Holmes: the life and times of Sir Arthur Conan Doyle. USA: Free Press, 2007.

MAST, Gerald. Literature and film. In: BARRICELLI, Jean Pierre.; GIBALDI, Joseph. (eds). Interrelations of literature. New York: MLA, 1982.

MARINARO, Francesca. M.; THOMAS, Kayley. "Don't make people into heroes, John": (Re/De)constructing the detective as hero. In: PORTER, Lynnette. (ed.). Sherlock Holmes for the 21st century: essays on new adaptations. USA: McFarland, 2012.

MELDRUM, Claire. Yesterday's women: the female presence in neo-Victorian television detective programs. Journal of Popular Film and Television, v. 43, n. 4, p. 201-211, dec. 2015.

MITTELL, Jason. Complex $T V$ : the poetics of contemporary television storytelling. USA: New York University Press, 2015.

MITTELL, Jason. Film and television narrative. In: HERMAN, D. (ed.) The Cambridge companion to narrative. UK: Cambridge University Press, 2007.

POLASEK, Ashley D. Surveying the post-millennial Sherlock Holmes: a case for the great detective as a man of our times. In: Adaptation. v. 6, n. 3, p. 384-393, 2013.

SHERLOCK. Created by: Mark Gatiss, Steven Moffat. Produced by: Mark Gatiss, Steven Moffat, Beryl Vertue, Rebecca Eaton. UK: BBC Wales, 2010 - present. 4 seasons, 15 episodes. $90 \mathrm{~min}$. son., color.

SHERLOCK Holmes. Directed by: Guy Ritchie. Written by: Michael Robert Johnson, Anthony Peckham, Simon Kinberg. Produced by: Bruce Berman. USA: Warner Bros., 2009. $128 \mathrm{~min}$, son., col.

SHERLOCK Holmes baffled. Directed by: Arthur Marvin. USA: American Mutoscope \& Biograph, 1900. 1min, silent, b\&w. 
THE HOUND of the Baskervilles. Directed by: Sidney Lanfield. Written by: Ernest Pascal. Produced by: Gene Markey, Darryl F. Zanuck. USA: Twentieth Century Fox, 1939. 80min, son., b\&w.

TOADVINE, April. The Watson effect: civilizing the sociopath. In: PORTER, Lynnette. (ed.). Sherlock Holmes for the 21st century - essays on new adaptations. USA: McFarland, 2012.

VERSTRATEN, Peter. Film narratology. Toronto: University of Toronto Press, 2009. 